DOI: $10.2478 /$ rjp-2020-0013

\title{
ENCOUNTER WITH DEATH (I)
}

An Interrupted Dialogue

Alice Popescu ${ }^{28}$

\begin{abstract}
The article focuses on psychic mechanisms at work in a life experience of maximum intensity: imprisonment awaiting the death penalty. "Dialogue with death", the memories of Arthur Koestler on the most traumatic period of his life - his stay in the prison of Seville during the Spanish Civil War-was initially published in 1937, as an important part of the "Spanish Testament", and was in itself one of the most significant testimonial works of the $20^{\text {th }}$ century on the subject of death. The perspective to which we have subjected it draws on psychoanalysis and is based, more precisely, on the Freudian theory on defenses against traumatic affects.
\end{abstract}

Keywords: Koestler, imprisonment, death sentence, Spanish Civil War, defense mechanisms.

\section{The Interlocutor}

In the autumn of 1937 Arthur Koestler writes and publishes his memories of the months spent in prison between February and March of the same year. The memories are recent and he doesn't want the experience to fade away. Besides, he has managed to save the diary notes taken at the time. Why this need to evoke such a period of his life, undoubtedly the most frightening? 
A "detail": these are the months lived while awaiting execution after having been sentenced to death by the nationalists of General Franco. During the civil war, he went on three visits to Spain, as a journalist accredited by the British newspaper News Chronicle. It was, in reality, a cover for his collaboration with the Comintern (Communist International). On the third visit he was apprehended and sentenced to death, hence the title of his book (Dialogue with Death). In the first edition, published in the U.K., Dialogue with Death constitutes the second part of the autobiographical volume Spanish Testament.

A dialogue involves the presence of another. Most of the time, Arthur Koestler is alone in his prison cell. Only towards the end of his time as an inmate of the Seville prison does he share this solitude, for a short while, with another prisoner. However, even during those last days, his main conversation partner remains death, the most poignant, most distinct presence of all that surrounds him. In reading the text, one cannot escape the impression that this special interlocutor is censored, or rendered mute: "Bearing in mind the fact that I was to write only nice things I worded in the style of the UncleBertie-seriously-ill-inform-Auntie telegram. If at night ten prisoners were shot, I wrote: Woke at ten, bad dreams." (Koestler, 1937, p.301) It is an act of precaution, meant to reduce damage in the event his diary is discovered by the guards. But it also protects himself against the imminence of this omnipresent "interlocutor" whom he is destined to meet. Trying to imagine how his death would occur, he concludes: "So why get agitated, when it all passes? Up to now I have kept myself under control and not written about these things. I must not do so again; it agitates me too much.” (Koestler, 1937, p.311)

\section{Zero... is Infinite}

Despite his efforts, the thoughts about the end often return to mind, where it is more or less consciously metabolized. When the author tries to appropriate death, he also discovers "advantages" in it: "Our life was, of course, an unusual one compared with normal prison life; the constant nearness of death weighed down and at the same time lightened our existence. Most of us were not afraid of death, only of the act of dying; and there were even moments in which we overcame even this fear. At such moments we were free - men without shadows, dismissed from the ranks of the mortal; it was the most complete realization of freedom that can be granted a man." 196 
(Koestler, 1937, p.371) To a well-trained reader, versed in the works of the Dialogue with Death's author, this might recall the Koestlerian infinite of which young Arthur had the revelation when he was only 12 years old, while looking at an arrow that was piercing the sky. (Laval, 2005, p.19) Even if the comparison is not explicit in the text, one might think of it, especially knowing that, after his release from prison, Koestler would forever renounce his communist convictions. This image (recurrent and emblematic in his writings) comes to mind when he evokes time and death: "Now I know that an inexorable law prevails: increasing awareness of time slows down its pace, complete awareness of time would bring it to a standstill. Only in death does the present become reality; time freezes - he who succeeds in experiencing pure time experiences nothingness." (Koestler, 1937, pp.323-324) This feeling was probably experienced by the author as a sort of epiphany, despite his well-known agnosticism at the time ... The dialogue with death, this zero moment in his life, freed him from one of the ideologies to which he had dedicated (as any true believer does) an important part of his tumultuous life.

Death frees people... he notes ... so for someone on death row, it becomes the only means to escape imprisonment, especially when life itself is perceived as a prison, to which only the end can deliver its true value or (when surviving an imminent death threat) its utmost intensity. Koestler's thoughts evoke the wisdom of a Buddhist recounting an experience on the verge of enlightenment. In his biography, L'homme sans concessions. Arthur Koestler et son siècle (The Man Without Concessions. Arthur Koestler and His Century), Michel Laval also underlines this aspect: He would spend long hours "gazing out of the window", lost in a deep meditation that opened the gates to a new feeling, a sentiment until then unknown, a cosmic feeling that he would later call the "oceanic feeling"... (Laval, 2005, p.223) However, the author of Dialogue with Death does not seek the most dramatic words to shock or seduce his reader: from beginning to end, his writing remains a balanced testimony (even too dry at times), prompting us to suspect the existence of hidden meanings beyond its simplicity. This observation stays true for the entire book, which makes it everything but an easy-to-read autobiography. Obviously, for the author there is an important cathartic value attached to it, meant to release the trauma.

Death is not always directly faced. There are times when it is banished from the realm of reality into that of games. Koestler adapts a puberty game 
to the present conditions and transforms it into a different type of "Russian roulette". It is an attempt to force himself to get used to the idea of dying and, at the same time, to deprive death of its power through rituals of repetition and divination. Stripped of all control over his own life, in his fantasy, Koestler needs to be the master of the game himself, or at least to pretend to be so... Death can only happen once, so if we reduce it to repetition, its magic, its radiance, its mystery, all that it is made of will be diminished and tamed: « During the first two days I actually counted my shirt-buttons: reprievedshot-reprieved-shot. Then I gave it up because an unfavorable result always terrified me.» (Koestler, 1937, p.384) Yet fear eventually prevails. Imprisoned, A. Koestler goes through different states of mind: from anxiety to fear and from fear to a feeling of complete freedom despite all evidence, and, then again, back to fear. Each time, these mood swings correspond to his own way of assuming death at a given moment: sometimes death is seen as inevitable, other times it is ignored, thanks to the hope that continues to reside in his heart or thanks to the simple fact of still being alive. The author notes: „The joke is one can't really ever completely convince oneself that the whole thing is reality and not an obscure game. Who really believes in his own death? [...] If it were not so, how could I feel as I write this that the whole thing is a theoretical discussion which doesn't concern me in the least?" (Koestler, 1937, p.310) Knowing that you are going to die and truly believing it are two different things. Being aware of one's own death is not a state of mind that can be maintained for long, even under the constant threat of annihilation: "I don't believe that since the world began a human being has ever consciously died." (Koestler, 1937, p.310)

But what kind of death is the one Koestler bears witness to? And what is its relation with imprisonment and, consequently, with freedom?

Obviously, the death Koestler converses with is not a natural demise nor an end he himself has decided on, but one imposed by a conjunctural justice, a condemnation meant to be exemplary for the enemy. The condemned must be stripped of his human condition, deprived of his rights, among which freedom remains the most important. Isolation is only a preparation, the beginning of a nothingness where there is no further or farther, neither exit, nor way back. For a death row inmate, prison is a one-way street.

Consequently, this type of death comes after a transformation that only imprisonment can bring about: the disappearance of self-esteem. Koestler 198 
admits looking at his jailers as if they were superior beings. His confession is rid of all illusions: „Now it is beginning to dawn on me what the slave mentality really is." (Koestler, 1937, p.308)

\section{The Defenses}

If Koestler participates directly in the Spanish Civil War, along with other writers from all over the world (Aragon, Malraux, Saint-Exupery, Orwell, Hemingway, Dos Passos, Neruda, Weil etc. on the side of the Republicans or Drieu la Rochelle, Claudel on the Nationalists' side), Sartre only contents himself with writing on the subject. In The Wall, his main character, Pablo Ibbieta, a Republican prisoner who awaits his execution in the company of two other convicts, keeps his hardness of character intact, displaying a conspicuous lack of empathy for his cellmates and colleagues in agony ... As far as he is concerned, he never seems to lose his self-esteem, the only weakness displayed in the vicinity of death being the conversion of anxiety into sweat. The others, weaker and more vulnerable to the death panic (in other words, more human like), seem overwhelmed not only by transpiration, but also by uncontrollable shivers and tremors. (Sartre, 1939, pp.16-39) The fact that Sartre himself had not experienced receiving a death sentence by the time he wrote The Wall might explain the different attitudes in facing one's own annihilation between his main character and Koestler. However, Malraux, who also came close to death on July $22^{\text {nd }}, 1944$, in a simulacrum of an execution staged by the Gestapo speaks of nothingness (Malraux, 1967, p.243) and admits (as the author of Dialogue with Death does) his inability to believe that he is going to die. (Malraux, 1967, p.218)

Like Koestler, he ruminates over his death, but seems unable to feel the sensations corresponding to such an experience or, in other words, he isolates in the unconscious the sensation linked to this affect which is, without doubt, the terrifying fear of being effectively reduced to nothing. As psychoanalysis defines it, isolation is a primary defense consisting in the removal of an unpleasant sensation from the level of the conscious. (Blackman, 2012, p.69)

In our case, to protect itself, the psyche removes from the conscious mind the disturbing sensation inspired by death, so the person remains aware of its imminence and can even try to represent it mentally (ideological content), but is not in contact with the sensation (anxiety). In the memoirs of 
Koestler and Malraux (both survivors of real encounters with death), isolation is present together with the negation or denial (Blackman, 2012, p.59): they know they're going to die, but they either don't think about it or they don't really believe it. Sometimes the two defensive mechanisms are intermittent or even absent: there are times when the ideological content is maintained in the conscious mind along with the feeling (anxiety), but not for long (see the previous quotes from the Koestlerian testimony). The plurality of defenses and their variations in synchrony or in diachrony are perfectly natural in the context, given that they are mobilized by a prolonged situation of danger.

The dialogue with death as a literary narrative is endless ... but the writings testifying to a detention prior to the death penalty remain particularly revealing for the psychoanalytic perspective. For that matter, Arthur Koestler's Dialogue with Death is one of the most moving and particularly disturbing works, given the fate of the author: he ended up committing suicide with his wife, Cynthia, at the age of 77. The suicidal act might have been his way to have the last word in this dialogue of youth, interrupted way back in Spain ... or a declaration of freedom (see liberation / feeling of infinity), together with the restoration of his self-esteem as a human being, seriously injured during that first confrontation with death.

\section{Conclusions}

Freud was the first to introduce in psychoanalysis the concept of death anxiety and to speak about one's impossibility to imagine their death, due to a sense of immortality that seems to be intrinsic to the unconscious (Freud, 1915/1955, p.289). In 1920, with the publication of Beyond the Pleasure Principle, he brings about one of his most influential and controversial ideas: the existence of a death instinct in the human psyche. But Freud's findings seemed (and still do) either too culturally grounded for the scientific taste (the concept of death instinct) or clinically limited to rather physically healthy people with psychological pathologies, as none of his observations related to what was going on with mentally normal people facing life-threatening experiences. It was Helen Kubler-Ross who opened that chapter in 1969, with the famous On Death and Dying, describing the emotional stages (denial, anger, bargaining, depression, and acceptance) that terminally ill patients were going through when confronting with the imminence of life ending. 200 
Prisoners awaiting their execution represent, in fact, a particular case study and the existence of autobiographical works testifying about their experiences could be an important asset for the psychoanalyst. As a matter of fact, in Thoughts for the Times on War and Death, Freud points out to the existence of an interesting territory still to be explored: that of the changes in the psychology of combatants, a subject he admits having little knowledge of (Freud, 1915/1955, p.287). In this regard, Arthur Koestler's Dialogue with Death seems to be one of the best references for a researcher willing to expand their area of observation. As previously discussed in this article, at least several psychoanalytically recognizable attitudes towards the imminent life ending drew our attention in his confessions: the denial of death, the acknowledgement of human impossibility to maintain or even attain death awareness, as well as the isolation of the affect. But probably the most interesting of all is the temporal (and formal) regression to a previous period in his life and to the person he was at that stage. Koestler plays a puberty game meant to evoke (by the ritualistic repetition of words and by placing himself in the position of the master of game) a feeling of control over the uncontrollable nature of death and, at the same time, to transport it from the realm of reality (future/ imminent denouement) into that of the unreal, of timeless probabilities. The abandonment of the logical thinking for a symbolic one (the "logic" of the game) suggests (as already mentioned) a formal regression, with the help of which the adult condenses his present image with that of the pre-adolescent he once was. By doing so, on one hand he makes sure to place himself far from death (at puberty, one is closer to the beginning of their life, rather than to the end of it) and on the other hand, he bans death from the level of consciousness back into that of the unconscious (thus locking it up in a sort of psychic chest as if he closed an invisible circle) where immortality reigns... This reprieved-shot-reprieved-shot game, mixing up the well-known childhood-to-adolescence game "she loves me-she loves me not" with the macabre stake of the Russian roulette as a compromise between life and death, still evokes the horrifying possible outcome of the latter, so that the idea of death be allowed to resurface at some point (the author stops playing it terrified at the thought of an unfavorable result) and to leave room for the other defenses to take over. The invisible circle, the trajectory of the affect tied to death travelling from the deeper layers of the psyche to the more superficial ones and back, closes itself as an Ouroboros eating its 
own tail. This becomes obvious when analyzing the type of game the writer plays with himself while awaiting his execution. The fact of choosing not exactly one from his early childhood, which could have offered him a more reassuring distance from death (childhood is even temporally farther from death and "more" unaware of the latter's existence than pre-adolescence is) testifies for his ambivalence in regard to the matter: the author, on one hand, attempts to avoid the complete awareness of his own death and, on the other hand, to embrace it so that he could become free from it once for all.

Yet, we cannot end the present article without admitting that, when contemplating Arthur Koestler's life, as well as his memoirs, one realizes what a much richer material for further psychoanalytic inquiries on death and the death instinct they stand for...

\section{REFERENCES}

BLACKMAN, J. S. (2003). 101 apărari [101 Defenses]. Trei Publishing House, Bucharest. 2012.

FREUD, S. (1915[1957]). Thoughts for the Times on War and Death. SE XIV. Hogarth Press, London, pp.273-300.

KOESTLER, A. (1937). Dialogue with Death. In Spanish Testament. Victor Gollancz Ltd, London.

LAVAL, M. (2005). L'homme Sans concessions. Arthur Koestler et son siècle [The Man Without Concessions. Arthur Koestler and His Century]. Calmann-Lévy, Paris.

MALRAUX, A. (1967). Antimémoirs [Anti-Memoirs]. Gallimard, Paris.

SARTRE, J. P. (1939). Le mur [The Wall], Gallimard, Paris. 